\title{
PROFIL KUALITAS TIDUR PADA PASIEN STROKE AKUT DI BAGIAN NEUROLOGI RSUP PROF. DR. R. D KANDOU MANADO PERIODE NOVEMBER 2013 - DESEMBER 2013
}

\author{
${ }^{1}$ Marcos Mambrasar \\ ${ }^{2}$ Melke J. Tumboimbela \\ ${ }^{2}$ Mieke A. H. N. Kembuan \\ ${ }^{1}$ Kandidat Skripsi Fakultas Kedokteran Universitas Sam Ratulangi Manado \\ ${ }^{2}$ Bagian Neurologi RSUP Prof. Dr. R. D. Kandou Manado \\ Email: marcosmambrasar@yahoo.com
}

\begin{abstract}
Stroke is one of the primary causes of deaths and neurological disabilities in Indonesia. This brain condition is a medical emergency that has to be treated rapidly and accordingly. This study aims to determine the sleep quality of acute stroke patients that has been treated at neurological department in Prof. Dr. R. D. Kandou Hospital Manado from November 2013-December 2013. This study uses a prospective descriptive method with PSQI survey (Pittsburgh Sleep Quality Index). This study has 20 samples. The data obtained by interview using the PSQI survey. This study suggests that the majority of the respondents are having a poor quality of sleep by $80 \%$.
\end{abstract}

Conclusion : most of the stroke patients treated are having a poor sleep quality (80\%) and the remains are having a good one (20\%).

Keywords: stroke, neurogic, medical emergency, PSQI.

\begin{abstract}
Abstrak : Stroke merupakan salah satu penyebab kematian dan kecacatan neurologis utama di Indonesia. Serangan otak ini merupakan kegawat-daruratan medis yang harus ditangani secara cepat dan tepat. Penelitian ini bertujuan untuk mengetahui kualitas tidur pada pasien stroke akut yang dirawat di bagian neurologi RSUP Prof. Dr. R. D Kandou Manado periode November 2013 - Desember 2013. Penelitian ini dilakukan menggunakan metode deskriptif prospektif dengan menggunakan kuesioner PSQI (Piitsburgh Sleep Quality Index) Sampel yang diambil sebanyak 20 orang. Data diperoleh dengan cara wawancara dengan menggunakan kuesioner PSQI (Piitsburgh Sleep Quality Index). Hasil penelitian bahwa pada penelitian ini mayoritas responden mengalami kualitas tidur yang buruk yaitu sebanyak (80\%). Simpulan : Sebagian besar pasien stroke akut yang dirawat mengalami kualitas tidur yang buruk, yakni (80\%) dan (20\%) mengalami kualitas tidur yang baik.
\end{abstract}

Kata kunci : stroke, neurologis, kegawat-daruratan medis, PSQI

Stroke adalah suatu sindrom yang ditandai dengan gejala dan atau tanda klinis yang berkembang dengan cepat berupa gangguan fungsional otak fokal maupun global yang berlangsung lebih dari 24 jam atau lebih dapat menyebabkan kematian, yang tidak disebabkan oleh sebab lain selain penyebab vaskuler. Definisi ini mencangkup stroke akibat infark otak (stroke iskemik), per- darahan intraserebral (PIS) non traumatik, perdarahan subaraknoid (PSA). ${ }^{1}$

Selama ini faktor risiko stroke yang kita ketahui ada dua yaitu,faktor risiko yang tidak dapat dimodifikasi dan faktor risiko yang dapat dimodifikasi. Faktor risiko stroke yang tidak dapat dimodifikasi antara lain: usia, jenis kelamin, TIA, fibrilasi atrium, faktor genetik. Sedangkan, faktor 
risiko stroke yang dapat dimodifikasi antara lain: hipertensi, diabetes melitus, merokok, konsumsi alkohol, dislipidemia. $^{2}$

Ternyata selain faktor risiko di atas, gangguan kualitas tidur dalam dekade terakhir ini dipandang sebagai faktor potensial penyebab terjadinya stroke., Kualitas tidur meliputi aspek kuantitatif dan kualitatif tidur, seperti lamanya tidur, waktu yang diperlukan untuk bisa tertidur, frekuensi terbangun dan aspek subjektif seperti kedalaman dan kepulasan tidur. ${ }^{5}$ Established Population for Epidemiologic of the Elderly (EPESE) mendapatkan dari 9000 responden, sekitar $29 \%$ berusia diatas 65 tahun mengalami keluhan gangguan kualitas tidur.

Menurut Michaels Breus dalam Trihendra (2007), ketidakcukupan kualitas dan kuantitas tidur dapat merusak memori dan kemampuan kognitif. Bila hal ini berlanjut hingga bertahun-tahun, akan berdampak pada tekanan darah tinggi, serangan jantung, stroke, hingga masalah psikologis seperti depresi dan gangguan perasaan lain.

\section{METODE PENELITIAN}

Penelitian ini dilakukan menggunakan metode deskriptif prospektif dengan menggunakan kuesioner PSQI (Piitsburgh Sleep Quality Index) untuk mengetahui kualitas tidur pada pasien stroke akut yang dirawat di bagian neurologi RSUP Prof. Dr. R. D Kandou Manado periode November 2013-Desember 2013. Subjek penelitian adalah semua pasien stroke akut di bagian neurologi RSUP Prof. Dr.R.D Kandou Manado periode November 2013-Desember 2013 yang memenuhi kriteria inklusi.

\section{Kriteria inklusi}

a. Pasien yang dirawat di ruang perawatan neurologi dengan diagnosis stroke akut dan mempunyai data lengkap (diagnosis, nama, umur, jenis kelamin)

b. Bersedia menjadi subjek penelitian dengan menjawab kuesioner yang ada.

\section{Kriteria eksklusi}

a. Pasien tidak mampu berkomunikasi secara verbal.

b. Pasien dengan riwayat ketergantungan alkohol.

c. Pasien dengan riwayat gangguan psikiatri.

d. Pasien dengan penurunan kesadaran.

e. Pasien dengan penggunaan obat-obat hipnotik dan sedatif secara rutin.

\section{HASIL}

Dari penelitian yang telah dilakukan di Bagian Neurologi RSUP Prof. Dr. R. D Kandou Manado periode November 2013Desember 2013 didapatkan sebanyak 20 pasien stroke akut yang memenuhi kriteria inklusi.

Hasil penelitian ini disajikan dengan menampilkan karakteristik subjek penelitian dalam bentuk tabel dan penjelasannya.

\section{Jenis kelamin}

Berdasarkan Tabel 1 dapat diketahui bahwa jumlah penderita laki-laki sebanyak 17 orang (65\%) dan jumlah penderita perempuan sebanyak 7 orang (35\%). Jumlah penderita laki-laki pada penelitian ini lebih banyak daripada jumlah perempuan.

Tabel 1. Distribusi pasien stroke akut berdasarkan jenis kelamin

\begin{tabular}{ccc}
\hline Jenis Kelamin & $\mathbf{N}$ & $\mathbf{\%}$ \\
\hline Laki-laki & 13 & 65.0 \\
Perempuan & 7 & 35.0 \\
Total & 20 & 100.0 \\
\hline
\end{tabular}

\section{Umur}

Berdasarkan tabel 2 terlihat bahwa frekuensi terbanyak responden dengan usia 45-54 tahun yaitu 12 orang (60\%). Diikuti oleh responden dengan usia 55-64 tahun yaitu 7 orang (35\%) dan usia 34-44 orang yaitu 1 orang (5\%). 
Tabel 2. Distribusi pasien stroke akut berdasarkan umur

\begin{tabular}{ccc}
\hline Umur & $\mathbf{n}$ & $\mathbf{\%}$ \\
\hline $35-44$ & 1 & 5.0 \\
$45-54$ & 12 & 60.0 \\
$55-64$ & 7 & 35.0 \\
Total & 20 & 100.0 \\
\hline
\end{tabular}

\section{Kualitas tidur subjektif}

Berdasarkan Tabel 3 tampak bahwa sebagian besar dari responden (70\%) menyatakan kualitas tidur mereka cukup, sedangkan pada kelompok sangat baik (5\%), (15\%) menyatakan kualitas mereka baik dan (10\%) menyatakan kualitas tidur mereka buruk.

Tabel 3. Distribusi frekuensi kualitas tidur subjektif pada pasien stroke akut di Bagian Neurologi RSUP Prof. Dr. R. D Kandou Manado periode November 2013-Desember 2013

\begin{tabular}{lcc}
\hline $\begin{array}{l}\text { Kualitas Tidur } \\
\text { Subjektif }\end{array}$ & N & \% \\
\hline Sangat Baik & 1 & 5.0 \\
Baik & 3 & 15.0 \\
Cukup & 14 & 70.0 \\
Buruk & 2 & 10.0 \\
Total & 20 & 100.0 \\
\hline
\end{tabular}

\section{Latensi tidur}

Waktu yang dibutuhkan responden untuk tertidur didapatkan (25\%) dapat tertidur dalam waktu <15 menit, hampir setengahnya dari responden (45\%) dapat tertidur dengan waktu 16-30 menit, (30\%) baru dapat tertidur setelah menunggu 31-60 menit dan tidak seorangpun dari responden (0\%) yang menyatakan mereka dapat tertidur $>60$ menit.

\section{Durasi tidur}

Berdasarkan hasil penelitian diketahui dari responden (35\%) tidur pulas lebih dari 7 jam, sebagian responden (20\%) tidur selama 7 jam, (40\%) tidur 5-6 jam dan (5\%) tidur selama kurang dari 5 jam.

Tabel 4. Distribusi Frekuensi Latensi Tidur Pada Pasien Stroke Akut di Bagian Neurologi RSUP Prof. Dr. R. D Kandou Manado Periode November 2013-Desember 2013

\begin{tabular}{ccc}
\hline Latensi Tidur & $\mathbf{N}$ & $\mathbf{\%}$ \\
\hline$<15$ menit & 5 & 25.0 \\
16-30 menit & 9 & 45.0 \\
31-60 menit & 6 & 30.0 \\
$>60$ menit & 0 & 0.0 \\
Total & 20 & 100.0 \\
\hline
\end{tabular}

Tabel 5. Distribusi Frekuensi Durasi Tidur Pada Pasien Stroke Akut di Bagian Neurologi RSUP Prof. Dr. R. D Kandou Manado Periode November 2013-Desember 2013

\begin{tabular}{lcc}
\hline Durasi Tidur & $\mathbf{N}$ & $\mathbf{\%}$ \\
\hline$>7$ jam & 7 & 35.0 \\
7 jam & 4 & 20.0 \\
$5-6$ jam & 8 & 40.0 \\
$<5$ jam & 1 & 5.0 \\
Total & 20 & 100.0 \\
\hline
\end{tabular}

\section{Efisiensi tidur}

Berdasarkan Tabel 6 hasil penelitian untuk kelompok efisiensi tidur didapatkan responden (15\%) mempunyai efisiensi tidur lebih dari 85\%, tidak seorangpun yang mempunyai efisiensi tidur $75-84 \%$ dan $65-$ 74\% (0\%), sedangkan (85\%) mempunyai efisiensi tidur kurang dari 65\%.

Tabel 6. Distribusi Frekuensi Efisiensi Tidur Pada Pasien Stroke Akut di Bagian Neurologi RSUP Prof. Dr. R. D Kandou Manado Periode November 2013-Desember 2013

\begin{tabular}{ccc}
\hline Efisiensi Tidur & $\mathbf{N}$ & $\mathbf{\%}$ \\
\hline$>85 \%$ & 3 & 15.0 \\
$75-84 \%$ & 0 & 0.0 \\
$65-74 \%$ & 0 & 0.0 \\
$<65 \%$ & 17 & 85.0 \\
Total & 20 & 100.0 \\
\hline
\end{tabular}




\section{Gangguan tidur}

Berdasarkan Tabel 7 dapat diketahui bahwa tidak ada responden yang mengalami gangguan tidur pada satu bulan yang lalu (0\%), (20\%) responden mengalami gangguan tidur sekali dalam seminggu, (70\%) responden mengalami gangguan tidur satu sampai dua kali seminggu dan hanya (10\%) yang mengalami gangguan tidur lebih dari dua kali dalam seminggu.

Tabel 7. Distribusi Frekuensi Gangguan Tidur Pada Pasien Stroke Akut di Bagian Neurologi RSUP Prof. Dr. R. D Kandou Manado Periode November 2013-Desember 2013

\begin{tabular}{lcc}
\hline \multicolumn{1}{c}{ Gangguan Tidur } & $\mathbf{N}$ & $\mathbf{\%}$ \\
\hline $\begin{array}{l}\text { Tidak ada pada satu } \\
\text { bulan yang lalu } \\
\text { < sekali dalam }\end{array}$ & 0 & 0.0 \\
$\begin{array}{l}\text { seminggu } \\
\text { 1-2 kali dalam } \\
\text { seminggu }\end{array}$ & 4 & 20.0 \\
$\begin{array}{l}>2 \text { kali dalam } \\
\text { seminggu }\end{array}$ & 14 & 70.0 \\
Total & 2 & 10.0 \\
\hline
\end{tabular}

\section{Penggunaan obat tidur}

Distribusi penggunaan obat tidur ditampilkan dalam tabel 8, yang menunjukkan sebanyak (100\%) responden tidak ada yang menggunakan obat tidur dalam satu bulan yang lalu.

Tabel 8. Distribusi Frekuensi Penggunaan Obat Tidur Pada Pasien Stroke Akut di Bagian Neurologi RSUP Prof. Dr. R. D Kandou Manado Periode November 2013-Desember 2013

\begin{tabular}{lcc}
\hline Penggunaan Obat Tidur & $\mathbf{n}$ & $\mathbf{\%}$ \\
\hline Tidak ada dalam satu & 20 & 100.0 \\
bulan yang lalu & 0 & 0.0 \\
< sekali dalam seminggu & & \\
1-2 kali dalam seminggu & 0 & 0.0 \\
>2 kali dalam seminggu & 0 & 0.0 \\
Total & 20 & 100.0 \\
\hline
\end{tabular}

\section{Disfungsi siang hari}

Berdasarkan tabel 9 dapat diketahui bahwa sebanyak (10\%) responden tidak mengalami disfungsi pada siang hari, (25\%) mengalami disfungsi pada siang hari kurang sekali dalam seminggu, sebagian besar responden mengalami disfungsi pada siang hari yaitu sebanyak (65\%).

Tabel 9. Distribusi Frekuensi Disfungsi Siang Hari Pada Pasien Stroke Akut di Bagian Neurologi RSUP Prof. Dr. R. D Kandou Manado Periode November 2013-Desember 2013

\begin{tabular}{lcc}
\hline $\begin{array}{c}\text { Disfungsi Pada Siang } \\
\text { Hari }\end{array}$ & $\mathbf{n}$ & $\mathbf{\%}$ \\
\hline $\begin{array}{l}\text { Tidak ada dalam satu } \\
\text { bulan yang lalu } \\
\text { < sekali dalam } \\
\text { seminggu }\end{array}$ & 2 & 10.0 \\
$\begin{array}{l}\text { 1-2 kali dalam } \\
\text { seminggu }\end{array}$ & 5 & 25.0 \\
$>2$ kali dalam & 13 & 65.0 \\
seminggu & 0 & 0.0 \\
$\quad$ Total & & \\
\hline
\end{tabular}

\section{Kualitas tidur}

Berdasarkan tabel 10 dapat diketahui bahwa sebagian besar responden mengalami kualitas tidur yang buruk yaitu sebanyak (80\%) dan hanya (20\%) responden yang mengalami kualitas tidur baik.

Tabel 10. Distribusi Frekuensi Kualitas Tidur Pada Pasien Stroke Akut di Bagian Neurologi RSUP Prof. Dr. R. D Kandou Manado Periode November 2013-Desember 2013

\begin{tabular}{ccc}
\hline Kualitas Tidur & $\mathbf{N}$ & $\mathbf{\%}$ \\
\hline Baik & 4 & 20.0 \\
Buruk & 16 & 80.0 \\
Total & 20 & 100.0 \\
\hline
\end{tabular}

\section{BAHASAN}

Berdasarkan penelitian yang telah dilakukan di Bagian Neurologi RSUP Prof. 
Dr. R. D Kandou Manado periode November 2013-Desember 2013 didapatkan sebanyak 20 pasien stroke akut yang memenuhi kriteria inklusi untuk dijadikan subjek penelitian. Dari 20 responden, distribusi berdasarkan jenis kelamin menunjukkan bahwa pasien laki-laki lebih banyak daripada pasien perempuan, dimana perbandingannya hampir 2:1. Pasien lakilaki sebanyak 65\% dan perempuan 35\%. Jenis kelamin merupakan salah satu faktor risiko yang tidak dapat dimodifikasi. Hal ini sesuai dengan beberapa literatur yang menyebutkan bahwa penderita stroke lebih sering dijumpai pada laki-laki dibandingkan perempuan. $^{6}$

Umur juga merupakan salah satu faktor risiko yang tidak dapat dimodifikasi. Semakin bertambahnya usia maka fleksibilitas pembuluh darah semakin berkurang yang dapat meningkatkan risiko stroke. Dalam penelitian ini jumlah pasien stroke akut paling banyak adalah pada umur 45-65tahun, yakni (95\%) sedangkan hanya (5\%) <45 tahum. Sama halnya dengan penelitian yang dilakukan oleh dokter Kiking di RS H. Adam Malik yaitu sebanyak (55,6\%) paling banyak menderita stroke akut adalah usia 45-65 tahun. ${ }^{7,8}$

Kompenen pertama (kualitas tidur subjektif) berdasarkan hasil penelitian yang dilakukan, dapat diketahui bahwa secara subjektif sebagian besar pasien stroke akut memiliki kualitas tidur yang cukup, yaitu sebanyak (70\%). Pada penelitian ini hampir sebanding dengan penelitian yang dilkukan oleh Amelia (2012) di mana didapatkan sebanyak (63,2\%) responden memiliki kualitas tidur yang cukup. Komponen kedua (latensi tidur) pada penelitian yang dilakukan didapatkan sebanyak (45\%) responden membutuhkan waktu 16-30 menit untuk dapat tertidur. Penelitian yang dilakukan Mubarok \& Chayatin (2007) didapatkan sebanyak (50,1\%) responden membutuhkan waktu $<15$ menit untuk dapat tertidur. Pada orang normal waktu yang diperlukan untuk dapat tertidur adalah 10-15 menit. Faktor yang dapat mempengaruhinya antara lain kebiasaan makan sebelum tidur, kebiasaan merokok dimana kebiasaan ini dapat mengganggu tidur seseorang yang berdampak pada meningkatnya latensi tidur. $^{9}$

Komponen ketiga (durasi tidur) pada penelitian ini sebagian besar responden memiliki durasi tidur 5-6 jam yaitu sebanyak (40\%). Penelitian yang dilakukan oleh Asmadi (2008) didapatkan sebanyak (39,7\%) memiliki durasi tidur antara 6-7 jam. Kebutuhan tidur orang dewasa normal sekitar 7-9 jam. $^{10}$ Komponen keempat (efisiensi tidur) pada hasil penelitian menunjukkan bahwa sebagian besar responden memiliki kebiasaan tidur dalam rentang $<65 \%$ sebanyak (85\%). Sedangkan penelitian yang dilakukan oleh Carol (2007) didapatkan sebanyak (73,5\%) responden memiliki kebiasaan tidur dalam rentang $>$ 85\%. Efisiensi tidur dapat diketahui dengan membandingkan jumlah total waktu tidur dengan lama waktu seseorang ketika berada di tempat tidur kemudian dikalikan 100\%. Jumlah yang lebih dari 85\% menunjukkan bahwa tidur orang tersebut efisien dan jika kurang dari itu dikatakan tidak efisien. ${ }^{11}$

Komponen kelima (gangguan tidur) pada penelitian ini sebagian besar responden (70\%) mengalami gangguan tidur satu sampai dua kali seminggu. Penelitian yang dilakukan oleh Pieter (2011) didapatkan sebanyak (60,3\%) responden mengalami gangguan tidur sebanyak kurang dari sekali dalam seminggu. Gangguan tidur terjadi karena adanya gangguan pada irama sirkardian dimana terjadi pergeseran pada siklus irama tidur dan irama bangun. ${ }^{12}$ Komponen keenam (penggunaan obat tidur) pada penelitian ini tidak ada responden yang menggunakan obat tidur dalam satu bulan terakhir. Sedangkan pada penelitian yang dilakukan oleh Mubarok \& Chayatin (2007) didapatkan sebanyak (92,6\%) responden tidak menggunakan obat tidur. Penggunaan obat tidur dapat mengganggu tahap III dan IV tidur REM dimana pada obat tidur ini dapat menyebabkan seringnya terjaga pada malam hari. ${ }^{9}$

Komponen ketujuh (disfungsi pada siang hari) pada penelitian ini didapatkan sebagian besar responden mengalami disfungsi pada siang hari dlam satu sampai 
dua kali seminggu sebesar (65\%). Penelitian yang dilakukan Oliveira (2010) didapatkan sebanyak (41,2\%) responden tidak mengalami disfungsi pada siang hari selama satu bulan terakhir. Hasil penelitian ini menunjukkan, mayoritas responden mengalami kualitas tidur yang buruk yaitu sebanyak (80\%). Penelitian yang dilakukan oleh Juliana dkk (2008) didapatkan sebanyak (64,7\%) responden memiliki kualitas tidur yang buruk.

\section{SIMPULAN}

Berdasarkan hasil penelitian tentang profil kualitas tidur pada pasien stroke akut yang dirawat di Bagian Neurologi RSUP Prof. Dr. R. D Kandou Manado periode November 2013-Desember 2013, dapat disimpulkan bahwa pada penelitian ini sebagian besar pasien stroke akut yang dirawat mengalami kualitas tidur yang buruk, yakni (80\%) dan (20\%) mengalami kualitas tidur yang baik.

\section{SARAN}

Perlu adanya penyuluhan untuk menghindari faktor risiko stroke agar terhindar dari stroke, serta penelitian ini sangat baik jika dilanjutkan dengan penelitian analitik tentang hubungan kualitas tidur dengan pasien stroke.

\section{UCAPAN TERIMA KASIH}

Ucapan terima kasih disampaikan kepada dr. Corry Mahama, SpS (penguji I), dr Herlyani Khosama, SpS (penguji II) dan kepada semua pihak yang telah memberi masukan dan ggasan kepada penulis dalam penulisan secara langsung dan tidak langsung sehingg artikel ini dapat terselesaikan.

\section{DAFTAR PUSTAKA}

1. Warlow CP, Dennis MS, Gijn VJ, Hankey GJ, Sandercock PA, Bamford JM. Stroke: a practical guide to management. London: Blackwell Science; 2007.

2. Wiwit S. Stroke dan Penanganannya. Cetakan I. Depok: Katahati, 2010; h.28.

3. Sutantoro, Basuki. Bagian Ilmu Penyakit saraf Fakultas Kedokteran UGM SMF Penyakit Saraf RSUP Dr. Sadjito. Berkala Neuro Sains. 2000;(1):141-53.

4. Sherki YG, Rosenbaum Z, Melamed E, Offen D. Antioxidant therapy in acute central nevous system injury : Current state. Journal of American Society for pharmacology and Experimental Therapeutics. America: 2002;54:271-84.

5. Wavy W. The Relationship between Time Management, Perceived Stress, Sleep Quality and Academic Performance among University Students [homepage on the Internet]. Nodate [cited 2010 Nov 16]. Available from: http://libproject.hkbu.edu. hk/trsimage/hp/06636306.pdf.

6. Lumbantobing S. Stroke Bencana Peredaran Darah di Otak. Jakarta: FK-UI; 2007.

7. Kiking R. Pengaruh Suhu Tubuh Terhadap Outcome Penderita Stroke yang di Rawat di RS H. Adam Malik Medan. USU: 2003. Diunduh dari: http//library.usu.ac.id/download/fk/penysara f-kiking.pdf. Diakses: 27 Juli 2011.

8. Misbach J. Pandangan Umum Mengenai Stroke Dalam: Rasyid A, Soertidewi L, editor. Unit Stroke: Manajemen Stroke Secara Komprehensif. Jakarata: FKUI; 2007.

9. Mubarok W, Chayatin M. Buku Ajar Kebutuhan Dasar Manusia: Teori dan Aplikasi dalam Praktik. Jakarta: EGC; 2007.

10. Potter P, Perry A. Fundamental Keperawatan: Konsep, Teori dan Praktek (Edisi Keempat). Jakarta: EGC; 2006.

11. Carol S. The Pittsburgh Sleep Quality Index (PSQI) [homepage on the Internet]. 2007 [cited 2013 Jan 25]. Available from: http://consultgerim.org/uploads/File/trythis// try_this_6_1.pdf.

12. Iskandar, Japardi. Gangguan Tidur [Tesis]. Medan: Universitas Sumatera Utara; 2002. 